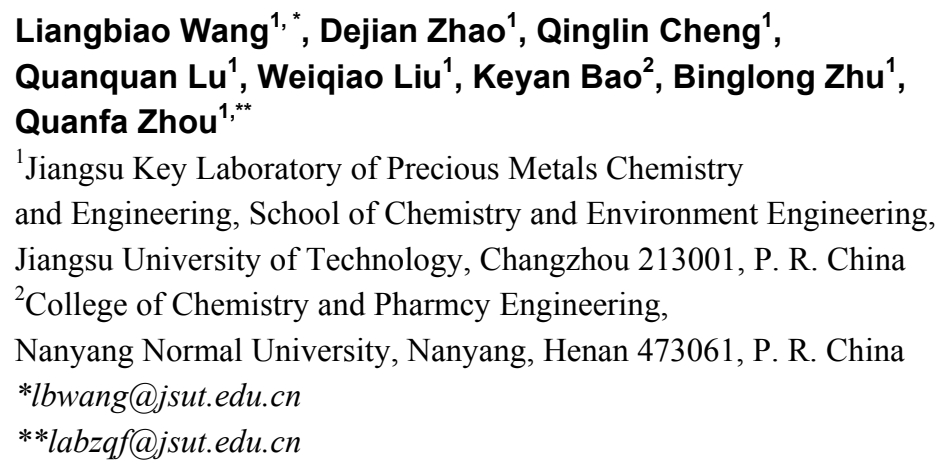

\title{
lodine-assisted solid-state synthesis and characterization of nanocrystalline zirconium diboride nanosheets
}

A solid-state route was developed to prepare zirconium diboride nanosheets with the dimension of about $500 \mathrm{~nm}$ and thickness of about $20 \mathrm{~nm}$ from zirconium dioxide, iodine and sodium borohydride at $700{ }^{\circ} \mathrm{C}$ in an autoclave reactor. The obtained $\mathrm{ZrB}{ }_{2}$ product was investigated by $X$-ray diffraction, scanning electron microscope and transmission electron microscopy. The obtained product was also studied by thermogravimetric analysis. It had good thermal stability and oxidation resistance below $400{ }^{\circ} \mathrm{C}$ in air. Furthermore, the possible formation mechanism of $\mathrm{ZrB}_{2}$ was also discussed.

Keywords: solid-state route, X-ray diffraction, zirconium diboride, nanosheets, chemical synthesis.

\section{INTRODUCTION}

Transition metal borides had attracted consideration interests because of their excellent properties, such as high melting point, high chemical stability, good electrical and thermal conductivity, and high hardness [1-4]. These various unique properties presented a wide range of applications, such as refractory lining materials, cutting tools, electronic materials and aerospace technologies. Among these, zirconium diboride $\left(\mathrm{ZrB}_{2}\right)$ was used widely in high temperature environments due to its high melting point $\left(3245^{\circ} \mathrm{C}\right)$, high thermal conductivity $\left(57.9 \mathrm{~W} \cdot \mathrm{m}^{-1} \cdot \mathrm{K}^{-1}\right)$, high hardness $(22 \mathrm{GPa})$, low density $\left(6.10 \mathrm{~g} / \mathrm{cm}^{3}\right)$, and good corrosion resistance $[5,6]$. In addition, $\mathrm{ZrB}_{2}$ was a superconductor with a very sharp superconducting transition at $5.5 \mathrm{~K}$ [7].

Up to now, several synthetic methods had been developed to synthesize $\mathrm{ZrB}_{2}$ materials, such as, the carbothermal reduction of zirconium dioxide and boron carbide $\left(\mathrm{B}_{4} \mathrm{C}\right)$ at $1400{ }^{\circ} \mathrm{C}$ [8], self-propagating high temperature synthesis (SHS) [9], high temperature reaction from a $\mathrm{ZrO}_{2}-\mathrm{C}-\mathrm{BN}$ precursor [10], solid-state reduction of zirconium dioxide and boron oxide by a metallic reducing agent (such as magnesium or aluminum) at temperatures of about $1500^{\circ} \mathrm{C}[11]$ and the mechanochemistry treatment of zirconia and amorphous boron at $1100{ }^{\circ} \mathrm{C}$ [12]. $\mathrm{ZrB}_{2}$ can 
also be prepared by chemical vapor deposition (CVD) from $\mathrm{ZrCl}_{4}, \mathrm{H}_{2}$ and $\mathrm{BCl}_{3}$ [13]. Amprphous $\mathrm{ZrB}_{2.76}$ was also obtained by thermolysis of zirconium precursor $\left(\mathrm{Zr}\left(\mathrm{BH}_{4}\right)_{4}\right)$ [14]. A general rout towards metal boride nanocrytals had been developed by ionothermal process at a relatively mild temperature $\left(500-900{ }^{\circ} \mathrm{C}\right)$ [15]. $\mathrm{ZrB}_{2}$ can also be obtained by a co-reduction method at low temperature $[16,17]$. Very recently, a solid-state reaction between zirconium dioxide and sodium borohydride was reported to produce pure nanosized $\mathrm{ZrB}_{2}$ at the temperature of $1100{ }^{\circ} \mathrm{C}$ [18]. Herein, we reported a solid-state reaction of zirconium dioxide and solid borohydride with iodine assisted to produce $\mathrm{ZrB}_{2}$ nanosheets at the temperature of $700{ }^{\circ} \mathrm{C}$ in an autoclave.

\section{EXPERIMENTAL}

All the reagents used in the experiments were purchased from Shanghai Chemical Reagents Company. All manipulations in our experiments were carried out in a glove box purged with flowing argon gas. In a typical procedure, zirconium dioxide $(0.25 \mathrm{~g})$, iodine $(0.54 \mathrm{~g})$ and sodium borohydride $(0.76 \mathrm{~g})$ were put into a stainless steel autoclave of $20 \mathrm{~mL}$ capacity. The autoclave was sealed and heated in an electric stove with a heating ramp rate of $10{ }^{\circ} \mathrm{C} / \mathrm{min}$ from room temperature to $700{ }^{\circ} \mathrm{C}$. The autoclave was maintained at $700{ }^{\circ} \mathrm{C}$ for $10 \mathrm{~h}$, and then followed by cooling to room temperature in the furnace naturally. The product collected from the autoclave was washed by absolute ethyl alcohol, distilled water and dilute $\mathrm{HCl}$ aqueous solution for several times to remove the impurities. Finally the final product was dried under vacuum at $60{ }^{\circ} \mathrm{C}$ for $10 \mathrm{~h}$ for further characterization.

$\mathrm{X}$-ray diffraction (XRD) pattern of the obtained product was performed with a Philips X'Pert X-ray powder diffractometer using $\mathrm{CuK \alpha}$ radiation $(\lambda=1.54178 \AA$ ). The microstructure of the obtained product was investigated with a field-emitting scanning electron microscope (FE-SEM, JEOL-JSM-6700F), a transmission electron microscope (TEM, H7650), and a high-resolution transmission electron microscope (HRTEM, JEOL-2010) with an accelerating voltage of $200 \mathrm{kV}$. Thermogravimetric analysis (TGA) profile was performed on a Shimadzu-50 thermoanalyzer apparatus under flowing air and argon below $1000{ }^{\circ} \mathrm{C}$ at a rate of $10{ }^{\circ} \mathrm{C} / \mathrm{min}$.

\section{RESULTS AND DISCUSSION}

XRD was used to check the crystal structure and the phase purity of the obtained product. A typical XRD pattern of the obtained product was shown in Fig. 1. All the peaks in Fig. 1 of the (001), (100), (101), (002), (110), (102), (111), (200), and (201) reflections can be indexed to pure hexagonal $\mathrm{ZrB}_{2}$ with lattice constants of $a=3.169 \AA$ and $c=3.543 \AA$, which were consistent with the reported values of hexagonal $\mathrm{ZrB}_{2}$ (Joint Committee on Powder Diffraction Standards (JCPDS) cards, No. 65-3389). No impurity peaks from $\mathrm{ZrO}_{2}$ or $\mathrm{Zr}$ were detected in Fig. 1, suggesting the $\mathrm{ZrB}_{2}$ product with high purity. All the peaks with strong diffraction intensity indicated the obtained $\mathrm{ZrB}_{2}$ with excellent crystallinity.

FE-SEM, TEM and HRTEM were used to study the microstructure of the obtained $\mathrm{ZrB}_{2}$ product. The FE-SEM image of the obtained $\mathrm{ZrB}_{2}$ is shown in Figs. 2, $a$ and $b$. The FE-SEM image (see Fig. 2, $a$ ) revealed that the $\mathrm{ZrB}_{2}$ product was composed of nanosheets and nanoparticles. A high-magnification image (see Fig. $2, b$ ) showed that the obtained $\mathrm{ZrB}_{2}$ product was composed of hexagonal plate and irregular nanosheets. The TEM image (Fig. 3,a) of the $\mathrm{ZrB}_{2}$ product showed the dimension of zirconium diboride $\left(\mathrm{ZrB}_{2}\right)$ nanosheets was about $500 \mathrm{~nm}$ with thickness of about $20 \mathrm{~nm}$ on average. In the HRTEM image (see Fig. 3, b), the 
obvious lattice fringes of hexagonal $\mathrm{ZrB}_{2}$ indicated that the obtained $\mathrm{ZrB}_{2}$ product was well crystalline. The plane intervals was measured to be about $0.22 \mathrm{~nm}$, which corresponded to the separation between (101) lattice planes of hexagonal $\mathrm{ZrB}_{2}$.

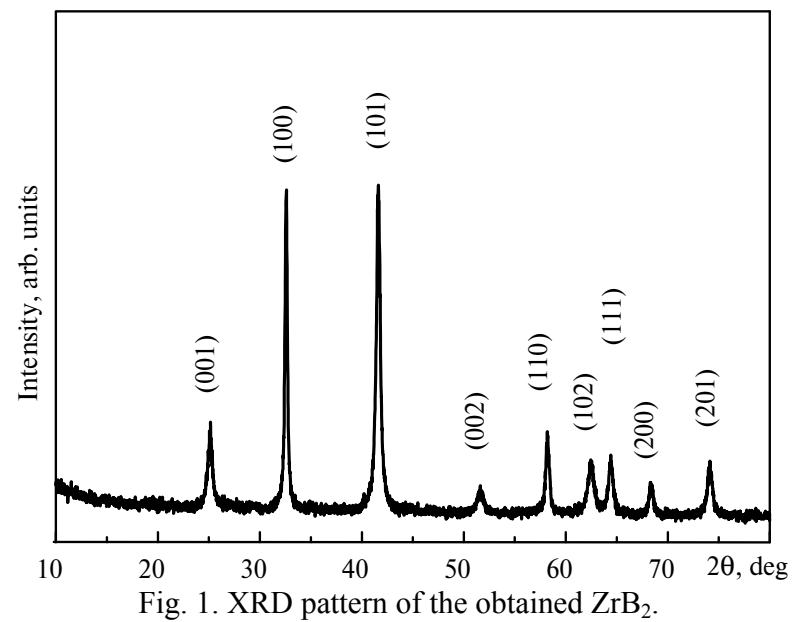

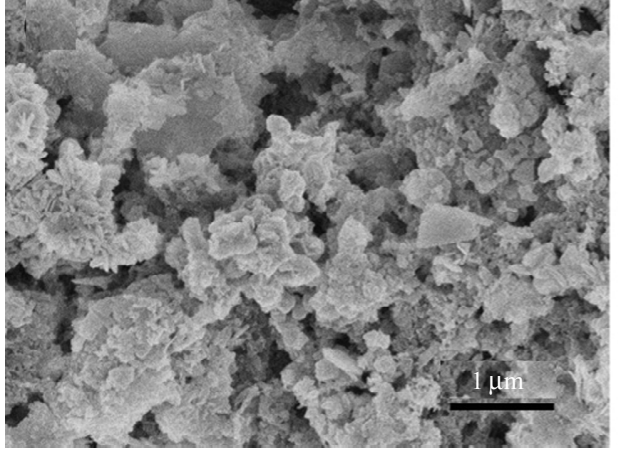

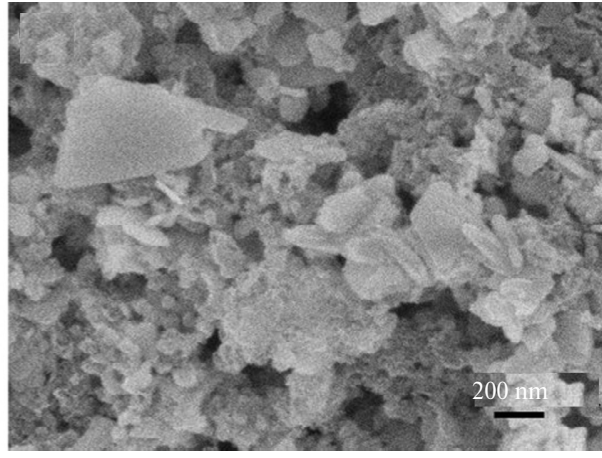

$b$

Fig. 2. FE-SEM images of the obtained $\mathrm{ZrB}_{2}$ product: low-magnification image (a), highmagnification image $(b)$.

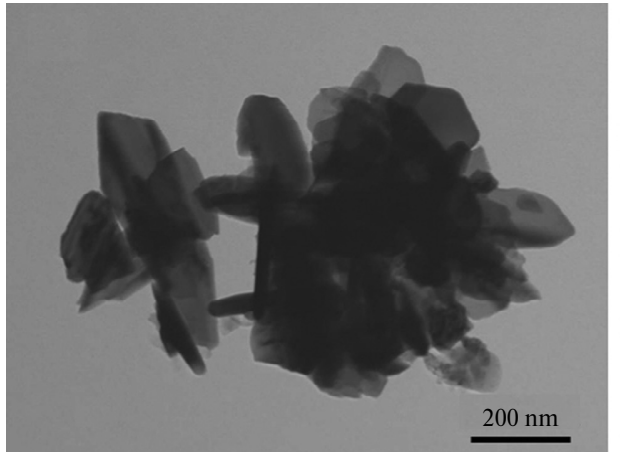

$a$

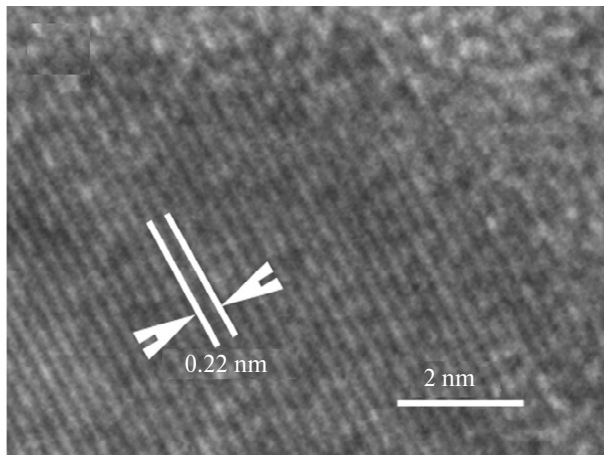

$b$

Fig. 3. TEM image of $\mathrm{ZrB}_{2}$ nanosheets (a), HRTEM image of $\mathrm{ZrB}_{2}$ nanosheets $(b)$.

The thermal stabilities and oxidation resistances of materials determine their application conditions. Thus, it is very important to study the thermal stability and oxidation resistance of the obtained $\mathrm{ZrB}_{2}$ product. The TGA of the $\mathrm{ZrB}_{2}$ is shown 
in Fig. 4. The TGA was carried out from room temperature to $1000{ }^{\circ} \mathrm{C}$ with a heating ramp rate of $10{ }^{\circ} \mathrm{C} / \mathrm{min}$ under flowing air and argon gases. The weight of the product from room temperature to $1000{ }^{\circ} \mathrm{C}$ under the flowing air is shown in the curve 1 . The TGA curve 1 shows that the weight of the product had not changed below $400{ }^{\circ} \mathrm{C}$. When the temperature is over $400{ }^{\circ} \mathrm{C}$, the $\mathrm{ZrB}_{2}$ product begins to oxidize to zirconium dioxide $\left(\mathrm{ZrO}_{2}\right)$ and diboron trioxide $\left(\mathrm{B}_{2} \mathrm{O}_{3}\right)$. The weight increment was about $55.2 \%$ by converting the $\mathrm{ZrB}_{2}$ into zirconium dioxide $\left(\mathrm{ZrO}_{2}\right)$ and diboron trioxide $\left(\mathrm{B}_{2} \mathrm{O}_{3}\right)$. The weight of the $\mathrm{ZrB}_{2}$ product from room temperature to $1000{ }^{\circ} \mathrm{C}$ under the flowing argon gas is shown in the curve 2 , which shows that the weight of the product was almost unchanged below $1000{ }^{\circ} \mathrm{C}$. The $\mathrm{ZrB}_{2}$ product obtained by our designed route had anti-oxidation behaviour under $400{ }^{\circ} \mathrm{C}$ and good thermal stability.

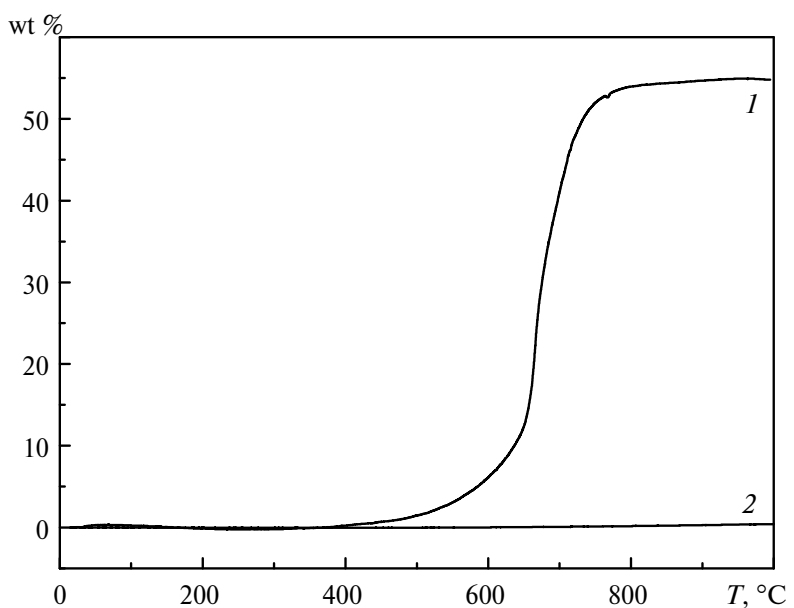

Fig. 4. TGA profile of the $\mathrm{ZrB}_{2}$ product under flowing air (1) and argon (2).

The possible formation mechanism of $\mathrm{ZrB}_{2}$ can be proposed here. The reaction between $\mathrm{ZrO}_{2}$ and $\mathrm{NaBH}_{4}$ used to produce $\mathrm{ZrB}_{2}$ was highly exothermic, but the reaction was initiated at high temperature of $1100{ }^{\circ} \mathrm{C}$. In our experimental process, the mole ratio of the raw materials is $\mathrm{ZrO}_{2}: \mathrm{I}_{2}: \mathrm{NaBH}_{4}=1: 1: 10$. With the assistance of iodine, hexagonal $\mathrm{ZrB}_{2}$ nanosheets were prepared from $\mathrm{ZrO}_{2}$ and $\mathrm{NaBH}_{4}$ in an autoclave, in which the exothermic reaction between iodine and $\mathrm{NaH}$ (coming from the pyrolysis of $\mathrm{NaBH}_{4}$ ) led to the formation of $\mathrm{ZrB}_{2}$ nanosheets at a relatively low temperature. The solid-state synthesis of crystalline $\mathrm{ZrB}_{2}$ by the reaction of $\mathrm{ZrO}_{2}$ and $\mathrm{NaBH}_{4}$ with $\mathrm{I}_{2}$ assisted in an autoclave can be described as follows

$$
\mathrm{ZrO}_{2}+6 \mathrm{NaBH}_{4}+\mathrm{I}_{2}=\mathrm{ZrB}_{2}+2 \mathrm{Na}_{2} \mathrm{O}+2 \mathrm{NaI}+6 \mathrm{H}_{2}+4 \mathrm{BH}_{3} .
$$

When the temperature increased over $500{ }^{\circ} \mathrm{C}$, the $\mathrm{NaBH}_{4}$, as the boride source, decomposed to $\mathrm{BH}_{3}$ and $\mathrm{NaH}$, which is shown in Eqs.

$$
\begin{aligned}
& \mathrm{NaBH}_{4}=\mathrm{NaH}+\mathrm{BH}_{3} ; \\
& 2 \mathrm{NaH}+\mathrm{I}_{2}=2 \mathrm{NaI}+\mathrm{H}_{2} .
\end{aligned}
$$

The possible formation process of $\mathrm{ZrB}_{2}$ nanosheets could be illustrated as follows

$$
\mathrm{ZrO}_{2}+2 \mathrm{BH}_{3}+4 \mathrm{NaH}=\mathrm{ZrB}_{2}+2 \mathrm{Na}_{2} \mathrm{O}+5 \mathrm{H}_{2}
$$


According to free energy calculations of the Eq. (3), the present solid state reaction is highly exothermic $\left(\Delta_{r} H_{m}=-462.84 \mathrm{~kJ} / \mathrm{mol}\right)$. A great deal of heat generated from the reaction of $\mathrm{NaH}$ and iodine and resulted in a high temperature in an autoclave, which favored crystallization of $\mathrm{ZrB}_{2}$. Meanwhile, $\mathrm{H}_{2}$ as byproduct coming from the Eq. (1) can bring high pressure in the autoclave, which is also beneficial to the formation of crystalline $\mathrm{ZrB}_{2}$. The influence of iodine and reaction temperature on the formation of $\mathrm{ZrB}_{2}$ was investigated. The optimal reaction temperature is $700{ }^{\circ} \mathrm{C}$. Although the present synthetic route is thermodynamically spontaneous, pure $\mathrm{ZrB}_{2}$ could not be obtained at the temperature of $600{ }^{\circ} \mathrm{C}$. In addition, iodine played a key role in the formation of $\mathrm{ZrB}_{2}$ nanosheets. $\mathrm{ZrB}_{2}$ cannot be obtained by the reaction of $\mathrm{ZrO}_{2}$ and $\mathrm{NaBH}_{4}$ at $700{ }^{\circ} \mathrm{C}$.

\section{CONCLUSIONS}

In summary, $\mathrm{ZrB}_{2}$ nanosheets with with the dimensions of about $500 \mathrm{~nm}$ and thickness of about $20 \mathrm{~nm}$ were successfully prepared at $700{ }^{\circ} \mathrm{C}$ in an autoclave by using zirconium dioxide, sodium borohydride and iodine as reactants. The $\mathrm{ZrB}_{2}$ nanosheets obtained by the designed route have anti-oxidation behaviour under $400{ }^{\circ} \mathrm{C}$ and good thermal stability. In comparison with previous synthetic routes, the present route has the advantages of utilizing inexpensive starting materials, simple apparatus and simple operation.

\section{ACKNOWLEDGEMENTS}

This work was supported by Natural Science Foundation of Jiangsu Province (No. BK20160292), Natural Science Foundation of the Higher Educations Institutions of Jiangsu Province (No. 16KJB150013), the National Natural Science Foundation of China (No. U1404505), the Program for Innovative Talent in University of Henan Province (16HASTIT010).

Розроблено твердотільний напрямок отримання наномарів дибориду цирконію розміром 500 нм і товщиною 20 нм з діоксиду иирконію, йоду та боргідриду натрію при $700{ }^{\circ} \mathrm{C}$ в автоклавному реакторі. Отриманий продукт $\mathrm{ZrB}{ }_{2}$ досліджували рентгенівською дифракцією, скануючим електронним мікроскопом і трансмісійною електронною мікроскопією. Отриманий продукт також вивчали термогравіметричним аналізом. Він мав гарну термостійкість $і$ стійкість до окиснення нижче $400{ }^{\circ} \mathrm{C}$ на повітрі. Крім того, обговорено також можливий механізм утворення $\mathrm{ZrB}_{2}$.

Ключові слова: твердотільна схема, рентгенівська дифракція, диборид ичрконію, нанорозміри, хімічний синтез.

Разработан твердотельный путь получения нанослоев диборида ичиркония размером 500 нм и толщиной 20 нм из диоксида ичиркония, йода и боргидрида натрия при $700{ }^{\circ} \mathrm{C}$ в автоклавной реакторе. Полученный продукт $\mathrm{Zr} B_{2}$ исследовали рентгеновской дифракцией, сканирующим электронным микроскопом и трансмиссионной электронной микроскопией. Полученный продукт также изучали термогравиметрическим анализом. Он имел хорошую термостойкость и устойчивость к окислению ниже $400{ }^{\circ} \mathrm{C}$ на воздухе. Кроме того, обсуждали также возможный механизм образования $\mathrm{ZrB}_{2}$.

Ключевые слова: твердотельная схема, рентгеновская дифракция, диборид циркония, наноразмеры, химический синтез.

1. Adams R. M. Boron, metallo-boron compounds and boranes. - New York: Interscience, 1964.

2. Samsonov G. V., Vinitskii I. M. Handbook of refractory compounds. - New York: Plenum Press, 1980.

3. Zhang G. J., Ji Z., Ni D. W., Liu H. T., Kan Y. M. Boride ceramics: densification, microstructure tailoring and properties improvement // J. Inorg. Mater. - 2012. - 27, N 3. - P. 225-233. 
4. Upadhya K., Yang J. M., Hoffman W. P. Materials for ultrahigh temperature structural applications // Am. Ceram. Soc. Bull. - 1997. - 76, N 12. - P. 51-56.

5. Fahrenholtz W. G., Hilmas G. E. Refractory diborides of zirconium and hafnium // J. Am. Ceram. Soc. $-2007 .-90$, N 5. - P. 1347-1364.

6. Ni D. W., Zhang G. J., Kan Y. M., Sakka Y. Highly textured $\mathrm{ZrB}_{2}$-based ultrahigh temperature ceramics via strong magnetic field alignment // Scripta Mater. - 2009. - 60, N 8. - P. 615618.

7. Gasparov V. A., Sidorov N. S., Zver'kova I. I., Kulakov M. P. Electron transport in diborides: Observation of superconductivity in $\mathrm{ZrB}_{2} / /$ JETP Lett. - 2001. - 73, N 10. - P. 532-535.

8. Zhao H., He Y., Jin Z. Z. Preparation of zirconium boride powder // J. Am. Ceram. Soc. 1995. - 78, N 9. - P. 2534-2536.

9. Camurlu H. E., Maglia F. Self-propagating high-temperature synthesis of $\mathrm{ZrB}_{2}$ or $\mathrm{TiB}_{2}$ reinforced Ni-Al composite powder // J. Alloys. Compds. - 2009. - 478, N 1-2. - P. 721-725.

10. Yan C. L., Liu R. J., Zhang C. R., Cao Y., Long X. Synthesis of $\mathrm{ZrB}_{2}$ powders from $\mathrm{ZrO}_{2}$, BN, and C // J. Am. Ceram. Soc. - 2016. - 99, N 1. - P. 16-19.

11. Schwarzkopf P., Kieffer R. Refractory hard metals. - New York: MacMillan Co., 1953.

12. Setoudeh N., Welham N. J. Formation of zirconium diboride $\left(\mathrm{ZrB}_{2}\right)$ by room temperature mechanochemical reaction between $\mathrm{ZrO}_{2}, \mathrm{~B}_{2} \mathrm{O}_{3}$ and $\mathrm{Mg} / / \mathrm{J}$. Alloys. Compd. - 2006. - 420, N 1-2. - P. 225-228.

13. Reich S. S., Hanko K., Szepes L. Deposition of thin-films of zirconium and hafnium boride by plasma enhanced chemical vapor-deposition // Adv. Mater. - 1992. - 4, N 10. - P. 650-653.

14. Andrievskii R. A., Kravchenko S. E., Shikin S. P. Preparation and some properties of ultrafine zirconium boride and titanium boride powders // Inorg. Mater. - 1995 - 31, N 8. - P. 965968.

15. Portehault D., Devi S., Beaunier P., Gervais C., Giordano C., Sanchez C., Antonietti M. A general solution route toward metal boride nanocrystals // Angew. Chem. Int. Edit. - 2011. - 50, N 14. - P. 3262-3265.

16. Chen L. Y., Gu Y. L., Shi L., Ma J. Yang Z. Low-temperature synthesis of nanocrystalline $\mathrm{ZrB}_{2}$ via Co-reduction of $\mathrm{ZrCl}_{4}$ and $\mathrm{BBr}_{3} / /$ Bull. Chem. Soc. Jpn. - 2004. - 77, N 7. P. $1423-1424$.

17. Zhu Y. C., Li Q. W., Mei T., Qian Y. Solid state synthesis of nitride, carbide and boride nanocrystals in an autoclave // J. Mater. Chem. - 2011. - 21, N 36. - P. 13756-13764.

18. Zoli L., Costa A. L., Sciti D. Synthesis of nanosized zirconium diboride powder via oxideborohydride solid-state reaction // Scripta Mater. - 2015. - 109. - P. 100-103.

Received 13.02.17 